\title{
Environmental sanitation factors as prevalence support of soil transmitted helminths
}

\author{
Edy Sapada ${ }^{1}$, Wita Asmalinda ${ }^{2}$ \\ ${ }^{1}$ Siti Khadijah Institute of Health Science Palembang, Palembang Indonesia \\ ${ }^{2}$ Health Polytechnic of the Ministry of Health, Palembang, Indonesia
}

\section{Article Info}

Article history:

Received March 30, 2021

Revised Jul 28, 2021

Accepted Aug 24, 2021

\section{Keywords:}

Soil transmitted helminths

Environmental sanitation

Source of drinking water

Place to defecate

\begin{abstract}
The prevalence of soil transmitted helminths (STH) is closely related to the defecation facilities for rural communities, such as: the habit of defecating openly on the ground, in gardens and using open latrines in rivers. The aim of this study was to determine the effect of environmental sanitation risk factors on the prevalence of STH infection. This study was included in an analytical epidemiological study at two locations, using a cross sectional study as the research design. The location were Sri Kembang Village, Bukit Village, which is included in Betung District, Banyuasin Regency, and South Sumatra, Indonesia for 30 days. There were 252 students as the research sample. Data analysis showed that the prevalence of $T$. trichiura was higher in Sri Kembang State Primary School Number 1 with mild to very severe infection degrees. The intensity of A. lumbricoides infection in Bukit State Primary School Number 1 got a higher prevalence than Sri Kembang. Open defecation, gardens or open latrines, and types of houses with dirt floors indicate environmental sanitation factors that are sufficient to support the prevalence of STH. For further research, it is recommended to examine socio-economic risk factors.
\end{abstract}

This is an open access article under the CC BY-SA license.

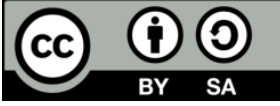

\section{Corresponding Author:}

Edy Sapada

Siti Khadijah Institute of Health Science Palembang

Demang Lebar Daun Road, RSI Siti Khadijah Complex, Palembang city, Indonesia

Email: ib_edys@yahoo.co.id

\section{INTRODUCTION}

Soil transmitted helminth (STH) is a nematode/intestinal worm which is in the life cycle and transmission process through soil media [1]-[4]. Trichuris trichiura, Ascaris lumbricoides, Ancylostoma duodenale, Necator americanus and Strongyloides stercoralis are five species of STH worms [2], [5], [6]. It is estimated that more than 1.5 billion people experience infection worldwide [7], [8], data from the Ministry of Health of the Republic of Indonesia shows that the STH infection rate ranges from $2.5 \%-62 \%$, especially among the poor and poor sanitation especially in rural areas [9]. The research location is in Betung subdistrict, Banyuasin district, which is located on the east coast of Sumatra Island, which has a wet tropical climate. The average temperature is $26,1^{\circ} \mathrm{C}-27,4^{\circ} \mathrm{C}$ with a relative humidity of $69.4 \%-85.5 \%$ Betung subdistrict has dry land with a slightly wavy topography (hilly), the soil type is podzolic, which is a supporting factor for the development and transmission of STH infection. The livelihoods of the population are mostly rubber farmers and gardening. The source of water comes from rivers and wells.

The prevalence of soil transmitted helminths (STH) infection is supported by several environmental factors, including; tropical and subtropical climates with high humidity and hot temperatures, soil type (warm and wet) [10], [11], soil particle properties and soil cultivation methods are supporting factors for the growth and development of the worm life cycle, soil particle properties and soil cultivation methods [6], If soil 
cultivation is carried out properly and correctly, it has an effect on the development of worms, so that the spread becomes low [12], the environmental sanitation factor is lacking [5], [6], physical house and yard with dirt floors, and high population density [13], sources of drinking water and food contaminated by worm eggs, both A.lumbricoides, T. trichiura, and hookworms [14].

The incidence of STH in rural areas is quite high, especially as a farmer who has direct contact with the land almost every day [6], [11], [14], [15]. The distribution of STH is closely related to the defecation facilities for rural communities, such as: the habit of defecating openly on the ground, in gardens and using open latrines in rivers. The soil, which is sandy, and loose with temperatures between $23^{\circ} \mathrm{C}-32^{\circ} \mathrm{C}$, is a good medium for larval growth [6], [14]. Clay media, moist and protected from sunlight are very favorable for the development of soil transmitted helminths (STH) worm eggs. In contrast to hookworms, this type of worm likes sandy, loose, humic soil media and is protected from direct sunlight because for the growth and development of worm larvae which require oxygen [16], [17].

In the body of the host, the larvae of the soil transmitted helminths (STH) develop into adult worms and in the process continue to reproduce by laying eggs. Eggs soil transmitted helminths (STH) worms come out with the feces of the host defecating in rivers and soil so that they can contaminate the soil and river environment. Whereas hookworm eggs will develop into infective filiform larvae in the soil. Hookworm infection is transmitted to humans by direct contact with soil contaminated by infective filiform larvae. Meanwhile, Ascariasis and Trichuriasis infection occurs if the eggs of infective worms are ingested by humans indirectly [18]. Other supporting factors are the lack of clean water facilities [8], the use of river water contaminated with worm eggs for daily activities such as for drinking, washing rice/ vegetables, washing dishes and kitchen utensils and defecating/urinating [5], [8].

Diagnosis of STH infection is confirmed by examining the feces and soil. Transmission can occur via direct transmission routes. Direct transmission occurs when infective eggs or cysts contaminate food, water, or soil, or it can occur when infective larvae in the soil come into contact with the host [4], [14]. The highest prevalence of worm infections according to World Bank data is at the elementary school age, aged 514 years [19]. Elementary school age children are included in the group that is at risk of worming because their play activities are oriented around the ground and rivers, so there is a big chance of being contaminated by hookworm larvae and worm eggs (A.lumbricoides and T. trichiura). From many studies on the topic of the prevalence of $S T H$ that the age of children is an age that must receive special attention, this is related to the results of studies which show that most infections occur in school-age children [20]. More than 1 billion people worldwide, especially in poor rural areas in developing countries are infected with earthworms (STH) [21], [22], and chronic infections with poly parasites often occur [23].

STH infection has a negative impact on nutritional status, anemia, physical, mental, cognitive growth in school-age children [12], [24]. Infestation of STH worms is endemic and a chronic disease caused by parasitic worms tends to be non-lethal but damage the body's health, which results in a decrease in the condition of nutrition and public health [25]. The prevalence of worms in Indonesia is $60 \%-90 \%$ depending on the location and environmental sanitation conditions [26]. The prevalence of worms increased in groups with poor environmental sanitation [18], [27].

According to research by Ali et al. [28], which concluded that there is a relationship between the availability of clean water and the incidence of worms, it is suspected that water is a basic human need, water is used for cooking, bathing and washing clothes and daily needs, so if the water used is not clean or is contaminated with worm eggs, it will cause a worm infection. According to Wahyuni [13] research, the high population density factor, with the distance between houses not more than 1-2 meters, so that sunlight is difficult to reach the ground as a result the soil around the settlement becomes moist, besides that the area is considered a flood-prone area which is thought to be a supporting factor high prevalence of STH [13]. According to Ngonjo et al. [23], in its development that at a temperature of $25^{\circ} \mathrm{C}-30^{\circ} \mathrm{C}$, the larvae are very favored by the larvae to hatch into eggs of A. lumbricoides worms, different things were obtained from research on $T$. trichiura larvae, that the eggs will mature at a temperature of optimum $30^{\circ} \mathrm{C}$. Research conducted by [21] concluded that environmental sanitation risk factors, namely the unavailability of clean water sources and proper latrines, are factors that must be improved and need attention and support from decision makers in order to reduce the prevalence of STH worms in elementary school students in rural areas. The aim of this study was to determine the effect of environmental sanitation risk factors on the prevalence of STH infection. This study focuses on seven environmental sanitation variables that are considered to have the most influence on the prevalence of STH.

\section{RESEARCH METHOD}

This study was an analytical epidemiological study at two locations, using a cross sectional study as the research design. The research location was at Bukit State Elementary School Number 1 and Sri Kembang State Elementary School Number 1, Betung District, Banyuasin Regency, Indonesia during the 30 days study 
period. The subjects in this study were all students of Bukit State Elementary School Number 1 and Sri Kembang State Elementary School Number 1. The sample size was 252 students in both elementary schools samples regardless of age and gender. All respondents were collected in class, accompanied by the school, all respondents were given an explanation of the purpose and benefits of this study, the procedure for taking stool samples and filling out questionnaires and Informed consent (this point was filled out and signed by the respondent's parents). Each student was asked to take a number of stool samples and submitted the next day together with a questionnaire and informed consent.

The variable that was determined was the prevalence of STH infection as the dependent variable, while the environmental sanitation factor was the independent variable. Trained officers in the parasitology laboratory, Faculty of Medicine, Sriwijaya University, were asked to assist directly at the research site to collect stool samples. Examination of eggs in feces using the Kato Katz method and the modified HaradaMori method. The equipment and materials used in the examination of the Kato Katz method include; cellophane measuring $2.5 \times 3 \mathrm{~cm}$, malachite green glycerin solution, with the ratio: $100 \mathrm{ml}$ glycerin, $100 \mathrm{ml}$ distilled water and one $\mathrm{ml}$ malachite green $3 \%$ in aquadest. For 18-24 hours before use, cellophane is immersed in a solution of malachite green glycerin, to filter stool samples using gauze with a size of approximately $3 \times 4 \mathrm{~cm}$, a thick cardboard measuring $3 \times 4 \mathrm{~cm}$ with a hole with a diameter of $6 \mathrm{~mm}$, wooden sticks, glass objects, lids. Rubber bottles, 10x10 cm filter paper, $10 \times 10 \mathrm{~cm}$ oil paper, sticks, microscope, and stool samples. The procedure for examining a stool sample is to use a sterilized stick, take a stool sample, and then the samples is placed evenly on the available oil paper, then takes gauze and then place it on the stool sample. Press the edges of the gauze so that the stool sample is filtered out; take the sample using the stick that has been prepared. Apply the stool sample to the vinyl hole that has been placed on a glass object, in the middle. Do this until the vinyl hole is full, and then remove the vinyl, and the bench located on the glass is covered with plastic that has been soaked in a bronze green glycerin solution. Cellophane is pressed with another glass object or a rubber bottle cap to flatten the stool under the plastic.

For 20-30 minutes the faecal preparations were drained by clamping and aerated upside down on filter paper. The dried faecal samples from each respondent were examined under a microscope, the eggs found were then counted manually, and then the number of eggs obtained was multiplied by 26 which is the number of eggs in one gram of feces. The Harada-Mori modification method uses equipment and discusses the following: plastic ice bags with holes in the ends, $4 \times 8 \mathrm{~cm}$ filter paper, wooden sticks, binocular microscope, scissors, spirit light lighters, distilled water, Lugol's solution, and stool samples. The procedure for examining worm eggs using the modified Harada-Mori method is: take a stool sample using a clean stick, then apply the sample on the filter paper lengthwise, and then put the filter paper into a plastic bag. Fill a plastic bag with distilled water until it touches the bottom of the filter paper. Then tightly close the top of the plastic bag by burning it, and then the stool sample is hung on a rope for 5-7 days. The larval examination procedure is: the preparation is prepared and then placed under a binocular microscope, to check the number of worm larvae. If larvae are found, the lower end of the plastic bag is cut off and the contents are placed in a petri dish. The larvae are killed by heating them on a spirit lamp or adding a few drops of Lugol's solution, and then the larvae are identified as one. Environmental sanitation data using a questionnaire that has previously been used by other researchers [29] and has been modified by researchers. Questionnaire sheets were distributed to each student to be taken home by the parents/guardians of the students. The research data were analyzed using statistical product and service solution (SPSS) version 20. This research has received an ethical approval recommendation from the Palembang Health Polytecnic Research Ethics Commission Number. 519 KEPK/Adm.2/XII/2020.

\section{RESULTS AND DISCUSSION}

Analysis of research data was carried out in stages for all research variables. To determine the distribution of each research variable used descriptive analysis. The next step is Fischer's exact test to analyze categorical data. The final stage is a regression test, which aims to find out how much influence the environmental sanitation variable has on the prevalence of STH.

The description of the distribution of parents' occupations, gender of respondents, in Bukit State Elementary School Number 1 students and Sri Kembang State Elementary School Number 1 are shown in the univariate analysis. Table 1 shows that the work of the respondent's parents as farmers is 34\% (Bukit state elementary school number 1) and 48.03\% (Sri Kembang State Elementary School Number 1). From 100 feces samples of respondents in Bukit State Elementary School Number 1 and 152 samples of respondents in Sri Kembang State Elementary School Number 1, who were examined, the intensity figures of $A$. lumbricoides, T. trichiura and hookworm infections were obtained. 
Table 1. Characteristics of respondents

\begin{tabular}{lcccc}
\hline Variable & $\begin{array}{c}\text { Frequency of Bukit State Elementary } \\
\text { School Number 1 } \\
\text { n (100) }\end{array}$ & $\begin{array}{c}\text { Frequency of Sri Kembang State Elementary } \\
\text { School Number 1 }\end{array}$ & $\%$ \\
\hline Parents' job & & & n (152) & \\
Labor & 26 & 26 & 9 & 5.92 \\
Farmer & 34 & 34 & 73 & 48.03 \\
Other & 40 & 40 & 70 & 46.05 \\
Gender & & & & 46.10 \\
Female & 38 & 38 & 70 & 53.90 \\
Male & 62 & 62 & 82 & \\
\hline
\end{tabular}

The Table 2 shows that the highest intensity of NEPG T. trichiura was at Sri Kembang State Elementary School Number 1 students, with a difference of $34.086 \%$, for the intensity of NEPG $A$. lumbricoides, the highest was at SDN Bukit with a difference of $12.696 \%$ and for the intensity of NEPG Hookworm was zero. In line with research [5], that at school age it is very rare to find hookworm eggs in stool samples. To find out the proportion of the intensity of the infection rate from the samples found in the students of Sri Kembang State Elementary School Number 1 and Bukit State Elementary School Number 1, using the classification of [27], [30], they were grouped into four categories, starting from very severe, severe, moderate and finally mild as shown in Table 3.

Table 2. The intensity number of A. lumbricoides, T. trichiura and hookworms in the respondent

\begin{tabular}{cccc}
\hline School & T. trichiura $(\%)$ & $\begin{array}{c}\text { Intensity (NEPG) } \\
\text { Hookworm (\%) }\end{array}$ & A. lumbricoides $(\%)$ \\
\hline Bukit State Elementary School Number 1 & $1.690(38.870)$ & 0 & $2.236(51.428)$ \\
Sri Kembang State Elementary School Number 1 & $3.172(72.956)$ & 0 & $1.684(38.732)$ \\
\hline \multicolumn{2}{c}{ Information: NEPG = Number of eggs per gram of feces = X x 23 (X is the number of eggs found) }
\end{tabular}

Table 3. The intensity of A. lumbricoides (Al), T. trichiura (Tt) and hookworms (Hw)

\begin{tabular}{|c|c|c|c|c|c|c|c|c|c|c|c|c|}
\hline \multirow[t]{3}{*}{ Degree of infection } & \multicolumn{6}{|c|}{$\begin{array}{l}\text { Bukit State Elementary School } \\
\text { Number } 1\end{array}$} & \multicolumn{6}{|c|}{$\begin{array}{c}\text { Sri Kembang State Elementary School } \\
\text { Number } 1\end{array}$} \\
\hline & \multicolumn{2}{|c|}{$A l$} & \multicolumn{2}{|c|}{$T t$} & \multicolumn{2}{|c|}{$\mathrm{Hw}$} & \multicolumn{2}{|c|}{$A l$} & \multicolumn{2}{|c|}{$T t$} & \multicolumn{2}{|c|}{ Hw } \\
\hline & $\mathrm{n}$ & $\%$ & $\mathrm{n}$ & $\%$ & $\mathrm{n}$ & $\%$ & $\mathrm{n}$ & $\%$ & $\mathrm{n}$ & $\%$ & $\mathrm{n}$ & $\%$ \\
\hline Light & 0 & 0 & 0 & 0 & 0 & 0 & 0 & 0 & 0 & 0 & 0 & 0 \\
\hline Moderate & 12 & 60 & 5 & 42 & 0 & 0 & 14 & 74 & 10 & 43 & 0 & 0 \\
\hline Weight & 8 & 40 & 7 & 58 & 0 & 0 & 4 & 21 & 13 & 57 & 0 & 0 \\
\hline Very heavy & 0 & 0 & 0 & 0 & 0 & 0 & 1 & 5 & 0 & 0 & 0 & 0 \\
\hline Total & 20 & 100 & 12 & 100 & 0 & 0 & 19 & 100 & 23 & 100 & 0 & 0 \\
\hline
\end{tabular}

Information:

Mild infection: 1 - 9 eggs/1 gram of feces

Medium: 10 - 99 eggs/1 gram of feces

Weight: 100 - 999 eggs/1 gram of feces

Very Heavy:> 1,000 eggs

To test the null hypothesis, whether accepted or rejected, a bivariate test was conducted between the prevalence variable of A. lumbricoides and the supporting environmental sanitation factors at Bukit State Elementary School Number 1. The results can be seen in Table 4. To test the alternative hypothesis (Ha), whether accepted or rejected, a bivariate test was carried out between the prevalence of $\mathrm{T}$. trichiura and the supporting environmental sanitation factors at Bukit State Elementary School Number 1. The result shows in Table 5. Multivariate analysis using logistic regression on seven variables of environmental sanitation factors as shown in Table 6.

From Table 6, it was found that the environmental sanitation factors supporting the prevalence of $T$. trichiura in Bukit State Elementary School Number 1, after the logistic regression test was found to have a significant relationship for the risk factors for all soils in the yard. To prove the hypothesis that environmental sanitation factors affect the incidence of A. lumbricoides in Sri Kembang State Elementary School Number 1, as shown in Table 7. Multivariate analysis using logistic regression on seven variables of environmental sanitation factors as shown in Table 8. 
Table 4. The relationship between environmental sanitation factors and the prevalence of $A$. lumbricoides in Bukit State Elementary School Number 1

\begin{tabular}{|c|c|c|c|c|c|c|}
\hline \multirow{2}{*}{ Environmental sanitation factor } & \multicolumn{2}{|c|}{ A. lumbricoides } & \multirow{2}{*}{ Total } & \multirow{2}{*}{ p-value } & \multirow{2}{*}{$\begin{array}{c}\text { Unadjusted } \\
\text { PR }\end{array}$} & \multirow{2}{*}{$95 \% \mathrm{CI}$} \\
\hline & Positive & Negative & & & & \\
\hline \multicolumn{7}{|l|}{ Source of drinking water } \\
\hline Rain river/open well & 18 & 75 & 93 & 0.625 & 0.600 & $0.108-3.346$ \\
\hline Closed well & 2 & 5 & 7 & & & \\
\hline \multicolumn{7}{|l|}{ Source of dishwashing water } \\
\hline Rain river/open well & 18 & 72 & 90 & 1.000 & 1.000 & $0.195-5.121$ \\
\hline Closed well & 2 & 8 & 10 & & & \\
\hline \multicolumn{7}{|c|}{ Sources of water for washing rice/vegetables } \\
\hline The river is open & 18 & 72 & 90 & 1.000 & 1.000 & $0.195-5.121$ \\
\hline Closed river & 2 & 8 & 10 & & & \\
\hline \multicolumn{7}{|l|}{ Place to defecate } \\
\hline There is no/garden/open latrine & 9 & 34 & 43 & 1.000 & 1.107 & $0.413-2.968$ \\
\hline Closed latrines & 11 & 46 & 57 & & & \\
\hline \multicolumn{7}{|l|}{ The loor at the front of the house } \\
\hline All land & 10 & 47 & 57 & 1.000 & 1.100 & $0.281-4.299$ \\
\hline All cement & 10 & 33 & 43 & & & \\
\hline \multicolumn{7}{|l|}{ House floor } \\
\hline All land & 17 & 74 & 91 & 0.378 & 0.459 & 0.104-2.024 \\
\hline All cement & 3 & 6 & 9 & & & \\
\hline \multicolumn{7}{|l|}{ Type of house } \\
\hline Not stilts/cement & 18 & 76 & 94 & 0.597 & 0.474 & $0.080-2.790$ \\
\hline Stage & 2 & 4 & 6 & & & \\
\hline
\end{tabular}

Table 5. The relationship between environmental sanitation factors and the prevalence of T. trichiura in Bukit State Elementary School Number 1

\begin{tabular}{|c|c|c|c|c|c|c|}
\hline \multirow{2}{*}{ Environmental sanitation factor } & \multicolumn{2}{|c|}{ T. trichiura } & \multirow{2}{*}{ Total } & \multirow{2}{*}{ p-value } & \multirow{2}{*}{$\begin{array}{c}\text { Unadjusted } \\
\text { PR }\end{array}$} & \multirow{2}{*}{$95 \% \mathrm{CI}$} \\
\hline & Positive & Negative & & & & \\
\hline \multicolumn{7}{|l|}{ Source of drinking water } \\
\hline Rain river/open well & 9 & 84 & 93 & $0.036^{*}$ & 0.143 & $0.028-0.742$ \\
\hline Closed well & 3 & 4 & 7 & & & \\
\hline \multicolumn{7}{|l|}{ Source of dishwashing water } \\
\hline Rain river/open well & 10 & 80 & 90 & 0.343 & 0.500 & $0.093-2.691$ \\
\hline Closed well & 2 & 8 & 10 & & & \\
\hline \multicolumn{7}{|c|}{ Sources of water for washing rice/vegetables } \\
\hline The river is open & 10 & 80 & 90 & 0.343 & 0.500 & $0.093-2.691$ \\
\hline Closed river & 2 & 8 & 10 & & & \\
\hline \multicolumn{7}{|l|}{ Place to defecate } \\
\hline There is no/garden/open latrine & 8 & 34 & 42 & 0.125 & 3.176 & $0.888-11.363$ \\
\hline Closed latrines & 4 & 54 & 58 & & & \\
\hline \multicolumn{7}{|l|}{ The floor at the front of the house } \\
\hline All land & 11 & 72 & 83 & 0.685 & 2.444 & $0.294-20.316$ \\
\hline All cement & 1 & 15 & 16 & & & \\
\hline \multicolumn{7}{|l|}{ House floor } \\
\hline All land & 12 & 85 & 97 & 1.000 & 0.876 & $0.813-0.944$ \\
\hline All cement & 0 & 3 & 3 & & & \\
\hline \multicolumn{7}{|l|}{ Type of house } \\
\hline Not stilts/cement & 8 & 53 & 61 & 0.761 & 1.321 & $0.369-4.721$ \\
\hline Stage & 4 & 35 & 39 & & & \\
\hline
\end{tabular}

Table 6. Results of environmental sanitation factor regression with prevalence of $T$. Trichiura in Bukit State Elementary School Number 1

\begin{tabular}{lccccc}
\hline \multicolumn{1}{c}{ Environmental Sanitation Factor } & \multirow{2}{*}{ Coefficient } & \multicolumn{2}{c}{ Unadjusted } & \multicolumn{2}{c}{ Adjusted } \\
& & PR & p & PR & p \\
\hline Source of dishwashing water & 15.951 & 0.500 & 0.343 & 86.038 & 0.999 \\
Place to defecate & 15.700 & 0.500 & 0.343 & 66.122 & 0.999 \\
The floor at the front of the house & 19.749 & 3.176 & 0.125 & 3.776 & 0.998 \\
Sources of water for washing rice/vegetables & 21.731 & 0.876 & 1.000 & 2.739 & 0.867 \\
Source of drinking water & 0.251 & 2.444 & 0.685 & 1.28 & 0.867 \\
House floor & -35.778 & 0.143 & 0.036 & 0.000 & 0.999 \\
Type of house & -17.992 & 1.321 & 0.761 & 0.000 & 0.998 \\
Constant & -18.320 & & & 0.000 & 0.999 \\
\hline
\end{tabular}


Table 7. The relationship between environmental sanitation factors and the prevalence of $A$. lumbricoides in Sri Kembang State Elementary School Number 1

\begin{tabular}{|c|c|c|c|c|c|c|}
\hline \multirow{2}{*}{ Environmental sanitation factor } & \multicolumn{2}{|c|}{ A. lumbricoies } & \multirow{2}{*}{ Total } & \multirow{2}{*}{$\mathrm{p}$-value } & \multirow{2}{*}{$\begin{array}{c}\text { Unadjusted } \\
\text { PR }\end{array}$} & \multirow{2}{*}{$95 \% \mathrm{CI}$} \\
\hline & Positive & Negative & & & & \\
\hline \multicolumn{7}{|l|}{ Source of drinking water } \\
\hline Rain river/open well & 17 & 98 & 115 & 0.163 & 0.901 & $0.808-1.004$ \\
\hline Closed well & 2 & 35 & 37 & & & \\
\hline \multicolumn{7}{|l|}{ Source of dishwashing water } \\
\hline Rain river/open well & 17 & 94 & 111 & 0.147 & 0.890 & $0.801-0.989$ \\
\hline Closed well & 2 & 39 & 41 & & & \\
\hline \multicolumn{7}{|c|}{ Sources of water for washing rice/vegetables } \\
\hline The river is open & 17 & 99 & 116 & 0.247 & 2.919 & $0.641-13.295$ \\
\hline Closed river & 2 & 34 & 36 & & & \\
\hline \multicolumn{7}{|l|}{ Place to defecate } \\
\hline There is no/garden/open latrine & 3 & 2 & 5 & $0.014 *$ & 0.449 & $0.153-1.315$ \\
\hline Closed latrines & 16 & 131 & 147 & & & \\
\hline \multicolumn{7}{|l|}{ The floor at the front of the house } \\
\hline All land & 11 & 34 & 45 & $0.009^{*}$ & 0.817 & $0,686-0.972$ \\
\hline All cement & 8 & 99 & 107 & & & \\
\hline \multicolumn{7}{|l|}{ House floor } \\
\hline All land & 12 & 91 & 103 & 0.844 & 0.791 & $0.291-2.154$ \\
\hline All cement & 7 & 42 & 49 & & & \\
\hline \multicolumn{7}{|l|}{ Type of house } \\
\hline Not stilts/cement & 10 & 88 & 98 & 0.370 & 0.568 & $0.215-1.498$ \\
\hline Stage & 9 & 45 & 54 & & & \\
\hline
\end{tabular}

Information * : Significant

Table 8. Results of environmental sanitation factor regression with prevalence of A. lumbricoides in Sri Kembang State Elementary School Number 1

\begin{tabular}{lccccc}
\hline \multicolumn{1}{c}{ Environmental sanitation factor } & \multirow{2}{*}{ Coefficient } & \multicolumn{2}{c}{ Unadjusted } & \multicolumn{2}{c}{ Adjusted } \\
& & PR & $\mathrm{p}$ & PR & $\mathrm{p}$ \\
\hline Source of dishwashing water & 2.161 & 0.449 & 0.014 & 8.677 & 0.014 \\
Place to defecate & 2.030 & 0.817 & 0.009 & 7.617 & 0.070 \\
The floor at the front of the house & 1.406 & 0.901 & 0.163 & 4.082 & 0.312 \\
Sources of water for washing rice/vegetables & 20.955 & 0.890 & 0.147 & 1.261 & 0.999 \\
Source of drinking water & -19.548 & 2.919 & 0.247 & 0.000 & 0.999 \\
House floor & -0.681 & 0.791 & 0.844 & 0.506 & 0.538 \\
Type of house & -0.681 & 0.568 & 0.370 & 0.020 & 0.005 \\
Constant & -1.927 & & & 0.146 & 0.104 \\
\hline
\end{tabular}

Table 8 proves that the source of dishwashing water in the open or in a place/container that is left open is very supportive of the occurrence of pollution which is very good for the development of $A$. lumbricoides eggs. The same risk is obtained if people defecate carelessly on the ground, or defecate in parks or if they have a latrine but it is not a healthy one. Unhealthy environmental sanitation should get the full attention of the local health office and also decision makers in the village. To break the chain of development of A. lumbricoides worms. There must be innovation from the community and local government in order to provide several boreholes or closed wells that can be used interchangeably by the poor who need them.

Efforts to control human physical environmental factors are environmental sanitation, efforts to control the environment that can adversely affect health, or efforts to protect and maintain environmental hygiene such as ensuring the availability of clean water, standardized disposal of feces and food handling and processing to avoid worm infections [11], [28]. Soil pollution due to the behavior of littering carelessly is a good medium for transmission of soil-transmitted helminths (STH). It is also related to the reference of soil polution with defecating in any place (defecating on the ground) [31]. To prove the hypothesis that environmental sanitation factors affect $T$. trichiura in Sri Kembang State Elementary School Number 1, it can be seen in Table 9. Multivariate analysis using logistic regression on seven variables of environmental health factors can be seen in Table 10 .

Table 10 proves that the type of house that is close to the ground strongly supports the occurrence of environmental pollution which is very good for the development of T. trichiura eggs. The risk is the same if the dishwashing water source comes from an open well water source/rainwater source, washing dishes and washing activities are carried out outside the house. It is better if the well is made of iron cover or can use a water suction machine so as to reduce the risk of contamination with T. trichiura worm eggs. 
Table 9. The relationship between environmental sanitation factors and the prevalence of T. trichiura in Sri Kembang State Elementary School Number 1

\begin{tabular}{|c|c|c|c|c|c|c|}
\hline \multirow{2}{*}{ Environmental sanitation factor } & \multicolumn{2}{|c|}{ T. trichiuara } & \multirow{2}{*}{ Total } & \multirow{2}{*}{ p-value } & \multirow{2}{*}{$\begin{array}{c}\text { Unadjusted } \\
\text { PR }\end{array}$} & \multirow{2}{*}{$95 \% \mathrm{CI}$} \\
\hline & Positive & Negative & & & & \\
\hline \multicolumn{7}{|l|}{ Source of drinking water } \\
\hline Rain river/open well & 16 & 99 & 115 & 0.635 & 0.693 & $0.261-1,841$ \\
\hline Closed well & 7 & 30 & 37 & & & \\
\hline \multicolumn{7}{|l|}{ Source of dishwashing water } \\
\hline Rain river/open well & 19 & 92 & 111 & 0.385 & 1.910 & $0.609-5.995$ \\
\hline Closed well & 4 & 37 & 41 & & & \\
\hline \multicolumn{7}{|c|}{ Sources of water for washing rice/vegetables } \\
\hline The river is open & 16 & 100 & 116 & 0.575 & 0.663 & $0.249-1.766$ \\
\hline Closed river & 7 & 29 & 36 & & & \\
\hline \multicolumn{7}{|l|}{ Place to defecate } \\
\hline There is no/garden/open latrine & 3 & 2 & 5 & $0.025 *$ & 0.463 & $0.158-1,357$ \\
\hline Closed latrines & 20 & 127 & 147 & & & \\
\hline \multicolumn{7}{|l|}{ The floor at the front of the house } \\
\hline All land & 10 & 35 & 45 & 0.182 & 2.066 & $0.831-5.139$ \\
\hline All cement & 13 & 94 & 107 & & & \\
\hline \multicolumn{7}{|l|}{ House floor } \\
\hline All land & 15 & 88 & 103 & 0.967 & 0.874 & $0.343-2.224$ \\
\hline All cement & 8 & 41 & 49 & & & \\
\hline \multicolumn{7}{|l|}{ Type of house } \\
\hline Not stilts/cement & 12 & 86 & 98 & 0.271 & 0.545 & $0.223-1.337$ \\
\hline Stage & 11 & 43 & 54 & & & \\
\hline
\end{tabular}

Table 10. Results of environmental sanitation factor regression with prevalence of T. Trichiura in Sri Kembang State Elementary School Number 1

\begin{tabular}{lccccc}
\hline \multicolumn{1}{c}{ Environmental sanitation factor } & \multirow{2}{*}{ Coefficient } & \multicolumn{2}{c}{ Unadjusted } & \multicolumn{2}{c}{ Adjusted } \\
& & PR & p & PR & p \\
\hline Source of dishwashing water & 2.294 & 0.449 & 0.014 & 9.913 & 0.026 \\
Place to defecate & 1.569 & 0.791 & 0.844 & 4.801 & 0.286 \\
The floor at the front of the house & 33.804 & 0.890 & 0.147 & 4.797 & 0.998 \\
Sources of water for washing rice/ vegetables & 0.625 & 0.817 & 0.009 & 1.869 & 0.327 \\
Source of drinking water & 16.363 & 1.901 & 0.163 & 0.000 & 0.999 \\
House floor & -17.025 & 2.919 & 0.247 & 0.000 & 0.999 \\
Type of house & -2.553 & 0.568 & 0.370 & 0.078 & 0.010 \\
Constant & -2.757 & & & 0.063 & 0.147 \\
\hline
\end{tabular}

The temperature factor has an effect on the development of worm eggs. The ambient temperature of $25^{\circ} \mathrm{C}$ is the best temperature for the growth of worm eggs. In an environment with temperatures below $20^{\circ} \mathrm{C}$ will inhibit the growth of worm eggs, but at this temperature can actually prolong the life of the eggs. Concluded that if the egg is at $37^{\circ} \mathrm{C}$ its growth stops at the eight-cell stage. Due to the environment there has been decay due to lack of charcoal [17], [19].

Sanitation consists of two complementary elements consisting of hardware (toilets, latrines, sewage treatment), and software (personal hygiene and regulations) [32]. In the context of economic development, it is the definitive intervention that eliminates STH infection. In groups of people with good hygiene and sanitation standards, STH infection has never been a health problem. Improvements in sanitation standards always have an impact on infection and reinfection rates. Children who are infected with worms will affect the process of growth and development [32]. These children have serious problems such as malnutrition, slow growth and development compared to other children of their age, iron anemia, delays in the development of the motor system. Severe whipworm infection in children can cause tricuric dysentery syndrome, the classic symptoms of which are stunted growth and anemia. The manifestation of roundworms and whipworms is a lack of protein energy. According to [33], identifying risk factors and dynamics of transmission and spread among vulnerable groups can support effective prevention planning programs. Efforts to improve personal hygiene practices in the school environment and improve environmental sanitation with community elements and supported by local governments can be alternative efforts to prevent new infections or reinfection [34]. Previous research [35] revealed that the habit of washing hands using running water and soap which is applied to children at school and at home, which is done regularly and becomes a habit, is an early protection from infection [35]. 


\section{CONCLUSION}

The prevalence of T. trichiura was higher in Sri Kembang State Primary School Number 1 with a degree of infection from mild to very severe. The intensity of A. lumbricoides infection in Bukit State Primary School Number 1 got a higher prevalence than Sri Kembang State Primary School Number 1. Open defecation, in gardens or open latrines, and the type of house with a dirt floor indicate that environmental sanitation factors are sufficient to support the prevalence of STH. Therefore, it is recommended to conduct health education about the importance of maintaining a clean environment, providing one healthy toilet for five families by rotating savings and credit system. For further research, it is recommended to examine socioeconomic factors variables.

\section{ACKNOWLEDEMENTS}

We gratefully thank to the Banyuasin District Health Office for the support and assistance provided during the research process.

\section{REFERENCES}

[1] BU. Palgunadi, "The Factors Affecting The Event Worms Caused by Soil-Transmitted Helminths in Indonesia," Medical Scientific Journal of Wijaya Kusuma. vol. Special Edition, pp. 6-12, 2010.

[2] S. Annisa, D. Dalilah, C. Anwar, and Novrikasari, "The Relationship between Soil-Transmitted Helminths (STH) Worm Infection and Nutritional Status in 200 State Elementary School Students, Kemasrindo Subdistrict, Kertapati District, Palembang City," Sriwijaya Medical Magazine, vol. 2, no. 2, pp. 92-104, 2018, doi: 10.32539/bsm.v2i2.39.

[3] R. Paun, W. Olin, and Z. Tola, "The Impact of Soil-Transmitted Helminths (STH) Towards Anemia Case in Elementary School Student in the District of Northwest Sumba," Global Journal of Health Science, vol. 11, no. 5, pp. 117-122, 2019, doi: 10.5539/gjhs.v11n5p117.

[4] I. E. Sapada, and W. Asmalinda, "Prevalence of Soil-Transmitted Helminths in Elementary School Students with Behavioral Risk Factors," Aisyah Journal: Journal of Health Sciences, vol. 5, no. 2, pp. 205-214, 2020, doi: 10.30604/jika.v5i2.368.

[5] S. P. Saskyarasmi, P. Sari, and S. Munfiah," The Relationship of Personal Hygiene and Sanitation with SoilTransmitted Helminths Infection in Elementary School Age Children around Landfills," Indonesian Journal of Education and Technology, vol. 1, no. 1, pp. 17-25, 2021, doi: 10.52436/1.jpti.

[6] A.R. Noviastuti, "Soil-Transmitted Helminths Infection," Majority Journal, vol. 4, no. 8, pp. 107-115, 2015.

[7] Rahmayanti, Razali, and Mudasir, "The Relationship of Knowledge, Attitude, and Actions with Soil-Transmitted Helminths (STH) Infection to Class 1, 2 and 3 Students of Pertiwi State Elementary School, Lamgarot District of Wish Jaya, Aceh Besar District," Biotic Journal, vol. 2, no. 2, pp. 77-137, 2014, doi: 10.22373/biotik.v2i2.244.

[8] World Health Organization, "Soil-Transmitted Helminth Infections," 2016, [Online]. Available: http://www. who.int/ medicacentre.

[9] I. G. G. Sastrawan, J. Setiabudi, N. P. Sanjiwani, N. K. Indriyani, and D. A. Laksemi, "Risk Factors of SoilTransmitted Helminth Infection among Primary School Students," Health Science Journal of Indonesia, vol. 11, no. 2, pp. 126-132, 2020, doi: 10.22435/hsji.v11i2.2885.

[10] P. N. Ngaluma, W. O. Arodi, G. M. Gachara, Kihara, J. H., and Nga'ng'a, M. P., "Schistosomiasis and Soil Transmitted Helminthiases in Taita Taveta County, Kenya: Prevalence, Intensity and Association with Anaemia and Nutritional Status of Children under 5 Years," J Infect Dis Diagn, vol. 5, no. 1, pp. 1-10, 2020, doi: 10.35248/2576-389X.5.131

[11] SJ. Campbell, NK. Biritwum, G. Woods, Y. Velleman, F. Fleming, and JR. Stothard, "Tailoring Water, Sanitation, and Hygiene (WASH) Targets for Soil-Transmitted Helminthiasis and Schisostomiasis Control," Trends Parasitol, vol. 34, no. 1, pp. 53-63, 2018, doi: 10.1016/j.pt.2017.09.004.

[12] Z. Riswanda and B. Kurniawan, "Soil-Transmitted Helminth infections : Ascariasis, Trichiuriasis and Hookworm," Medical Journal of Lampung University, vol. 5, no. 4, pp. 61-68, 2016.

[13] D. Wahyuni, "The Relationship of Nail Cutting Habits and usage Footwear on The Risk of STH Infection in Children at Sri Meranti Village, Rumbai District, Pekan Baru City," Journal of Midwifery Science, STIKES AlInsyirah Pekan Baru, vol. 5, no. 1, pp. 27-34, 2016.

[14] Sudarto, "Helmintology Texbook," Surabaya: Airlangga University Press, 2011.

[15] A. Primada et al., "Eosinophilia As A Predictor Morbidity of Soil-Transmitted Helminthiases Among Widodoren Plantation Workers in Jember," Journal of Vocation Health Studies, vol. 3, no. 2, pp. 47-52, 2019, doi: $10.20473 /$ jvhs.

[16] L. I. Alifia, "The Role of Water and Sanitation in Prevention of Soil-Transmitted Helminths," CoMPHI Journal: Community Medicine and Public Health of Indonesia Journal, vol. 2, no. 1, pp. 139-147, 2021, doi: 10.37148/comphijournal.v2i1.26.

[17] Minister of Health of the Republic of Indonesia, "Regulation of the Minister of Health of the Republic of Indonesia Number 15 of 2017," Concerning the Prevention of Worms, 2017, [Online]. Available: http://hukor.kemkes.go.id/uploads/produk_hukum/PMK_No._15_ttg_Penanggulangan_Cacingan_.pdf

[18] S. Sandy, S. Sumarni, and Soeyoko, "Risk Factor Model Analysis Affecting The Worm Infection Through SoilTransmitted Helminth at Primary Students in District Arso Keerom Regency," Research and Development Media, 
vol. 25, no. 1, pp. 1-14, 2015.

[19] NE. Clarke, AC. Clements, S. Bryan, J. McGown, D. Gray, and SV. Nery, "Investigating the differential impact of school and community-based integrated control programmes for Soil-Transmitted Helminths in Timor-Leste: the (S)WASH-D for Worms pilot study protocol. Pilot Feasibility Study," Pilot Feasibility Study., vol. 2, no. 1, pp. 110, 2016, doi: 10.1186/s40814-016-0109-4.

[20] TJ. Cepot-Robins et al., "Soil-Transmitted Helminth Prevalence and Infection Intensity among Geographicallyand Economically Distinct Shuar Communities in The Ecuadorian Amazon," Journal American Society of Parasitologists, vol. 100, no. 50, pp. 598-607, 2014, doi: 10.1645/13-383.

[21] Y. Shang, LH. Tang, SS. Zhou, YD. Chen, YC. Yang, and SX. Lin, "Stunting and Soil- Transmitted- Helminth Infactions among Sbhool Age Pupils in Rural Areas of Sounthern China," Journal Parasites and Vectors, vol. 3 , no. 97, pp. 1-6, 2010, doi: 10.1186/1756-3305-3-97.

[22] T. Alelign, A. Degarege, and B. Erko, "Soil-Transmitted Helminth Infections and Associated Risk Factors among Schoolchildren in Durbete Town, Northwestern Ethiopia," Journal of Parasitology Research, vol. 2015, no. 1, pp. 1-5, 2015, doi: 10.1155/2015/641602.

[23] T. Ngonjo et al., "Current Status of Soil-Transmitted Helminths among School Children in Kakamega County, Western Kenya," Journal of Parasitology Research, vol. 2016, pp. 1-9, 2016, doi: 10.1155/2016/7680124.

[24] I. B. Y. Brahmantya, H. H. Putra Iqra, I G. N. B. Rai Mulya Hartawan, I. A. Widya Anjani, I. M. Sudarmaja, C. R. Iqra, C. Ryalino, "Risk factors and prevalence of Soil-Transmitted Helminth infections," Open Access Macedonian Journal of Medical Sciences, vol. 8, no. A, pp. 521-524, 2020, doi: 10.3889/oamjms.2020.4440.

[25] L. Sofiana and MSJ. Kelen, "Factors Related to Soil Transmitted Helminth Infection of primary School Children," Unnes Journal of Public Health, vol. 7, no. 1, pp. 55-61, 2018, doi: 10.15294/ujph.v7i1.17400.

[26] B. Hairani, and L. Waris, Prevalence of Soil-Transmitted Helminths (STH) in Primary School Children in subdistrict of Malinau City, District of Malinau, East Kalimantan Province Prevalensi Soil-Transmitted Helminth, " Journal of Epidemiology and Animal Source, vol. 5, no. 1, pp. 43-48, 2014.

[27] D. Glinz et al., "Comparing Diagnostic Accuracy of Kato-Katz, Koga Agar Plate, Ether-Concentration, and FLOTAC for Schistosomamansoni and Soil-Transmitted Helminths," Journal Plos Neglected Tropical Diseases, vol. 4, no. 7, pp. 1-10, 2010.

[28] R. U. Ali, Z. Zulkarnaini, and D. Affandi, "The Relationship of Personal Hygiene and Environmental Sanitation with Incidence Rate Worms (Soil-Transmitted Helminth) in Vegetable Farmers in Maharatu Village, Marpoyan Damai District, Pekanbaru City," Indonesian Journal of Environmental Dynamics, vol. 3, no. 1, pp. 24-32, 2016, doi: 10.31258/dli.3.1.p.24-32.

[29] N.M. Nuryanti, and I.M. Subrata, "Soil-Transmitted Helminthiasis Infection in Elementary School Students in Highland and Lowland Areas of Gianyae Regency," Jurnal Kesehatan Mayarakat, vol. 13, no. 3, pp. 323-330, 2018.

[30] D. Yang et al., "Prevalence and risk factors of Ascaris lumbricoides, Trichuris trichiura and Cryptosporidium infections in elementary school children in southwestern China: A school-based cross-sectional study," International Journal of Environmental Research and Public Health, vol. 15, no. 9, pp. 1-16, 2018, doi: 10.3390/ijerph15091809.

[31] H. Samad, "The Relationship between Infection and Soil Pollution by Earthworms with Behavior of Elementary School Children in Tembung Village, Medan Tembung District," Thesis in Postgraduate Tropical Medicine Study Program, University of North Sumatera, 2009.

[32] M. Riaz et al., "Prevalence, risk factors, challenges, and the currently available diagnostic tools for the determination of helminths infections in human," European Journal of Inflammation, vol. 18, pp. 1-15, 2020, doi: $10.1177 / 2058739220959915$

[33] D. Kattula et al., "Prevalence \& Risk Factors for Soil-Transmitted Helminth Infection among School Children in South India," Journal Indian Journal Med. Res., vol. 139, no. 1, pp. 76-82, 2015.

[34] D. M. Damanik, Soeyoko, and A. H. Sutomo, "Sanitation of House and School, Personal Hygiene and Infection of Soil-Transmitted Helminths among Elementary School Students," International Journal of Public Health Science (IJPHS), vol. 3, no. 1, pp. 43-50, 2014, doi: 10.11591/ijphs.v3i1.4673.

[35] Z. Zerdo, T. Yohanes, and B. Tariku, "Soil-Transmitted Helminth Reinfection and Associated Risk Factors among School-Age Children in Chencha District, Southern Ethiopia: A Cross-Sectional Study," Journal of Parasitology Research, vol. 2016, pp. 1-7, 2016, doi: 10.1155/2016/4737891. 